\title{
An ecological framework for the strategic positioning of a shopping mall
}

Received (in revised form): 9 August 2006

\section{Chung-yim Yiu}

is currently an Assistant Professor in the Department of Real Estate and Construction, the University of Hong Kong. He is a qualified building surveyor, a professional facility manager, and a corporate member of the Hong Kong Institute of Surveyors, the Royal Institute of Chartered Surveyors, and the Hong Kong Institute of Facility Management. His research interests and expertise are in facility performance assessment, building maintenance, and property and construction economics and finance.

\section{Yung Yau}

received professional training in building surveying in the Buildings Department, the Government of Hong Kong Special Administrative Region after his graduation from the University of Hong Kong . Since 2004, he has been a PhD researcher in the Department of Real Estate and Construction, the University of Hong Kong. His research interests include development control, heritage conservation, real estate economics and finance, and building performance assessment.

\begin{abstract}
A well-planned and implemented strategic positioning is critical for the success of a shopping mall. Although strategic mall positioning has become a popular subject of both academic and practical research, the approaches from previous studies have been insubstantial. These studies failed to recognise the difference between positioning a consumer product and positioning a mall. In fact, what makes the positioning of a shopping mall differentiable is the dual-market (ie shopper market and retailer market) consideration. Being the first trial to look into mall positioning scientifically, this study formulates a framework to model the dynamic interaction among shoppers, retailers, other competing malls and also shops-on-street using the concept of community ecology. The retailing environment in a shopping mall is analogised to an ecosystem in which predators and prey coexist. A successful mall positioning strategy should be able to nurture an environment conducive to the development of all components in the system. The framework suggested in this study has far-reaching implications. It provides a more systematic approach to strategic mall positioning, which can facilitate the decision-making process of mall operators. In addition, the success determinants identified may provide a basis for comparing or benchmarking performance of the strategic positioning of different malls.
\end{abstract}

Yung Yau

Department of Real Estate and Construction

The University of Hong Kong Pokfulam

Hong Kong

Tel: +85228578625

Fax: +85225599457

E-mail: simonyau@hkusua.hku.hk

\section{Keywords:}

community ecology, shopping mall, strategic positioning 
Journal of Retail and Leisure Property (2006) 5, 270-280.

doi:10.1057/palgrave.rlp.5100037

\section{INTRODUCTION}

Malls in its original meaning refers to the tracts for strolling. Now most of the malls are shopping malls, tracts to stroll while you shop and to shop in while you stroll. The merchandisers sniffed out the attraction and seductive power of strollers' habits and set about moulding them into life. ... Shopping malls make the world safe for life-as-strolling. Or, rather, shopping malls are the worlds made by the bespoke designers to the measure of the stroller. (Bauman, 1993) ${ }^{1}$

Undoubtedly, shopping malls, which are planned retail facilities, have been playing important roles in the retail industry. In fact, the history of shopping mall development is long. Before cars, air-conditioning, or even electricity came the first shopping mall. This was the Galleria Vittorio Emanuele, which was built in Milan, Italy in 1878. After that, more malls were developed around the world. After decades of evolution, the world's first modern mall, designed by Victor Gruen, was built in Southdale, Minneapolis in the USA in 1956. Since then, there has been vigorous development of new shopping malls and their value to the retail industry has been commonly recognised. ${ }^{2}$

From the perspective of institutional economics, a shopping mall is set up to control excessive competition among retailers. With a single body of management, a mall provides the convenience of multipurpose shopping, but can avoid rent dissipation through excess capacity caused by independent retailers. ${ }^{3}$ By its very nature, a mall is typically a meticulously planned coalition of finance, construction and commercial capital. ${ }^{4}$ It provides a platform attracting both retailers and shoppers to make deals, but it works very differently from shops-on-street. Unlike other businesses, running a shopping mall is more than just selling products or services. On one hand, the mall developer or operator offers space for retailers. On the other hand, people come to shopping malls not just for shopping but also for the experience, the crowds, the art and the entertainment. ${ }^{5}$ Therefore, the success of a mall is determined by how well retailers can sell their products or services and how well shoppers can derive a benefit from shopping there. In other words, the mall acts like an agent who facilitates transactions between and stimulates the satisfactions of two stakeholders, namely retailers and shoppers. It is the presence of this synergy that makes a mall successful. Thus, a well-planned positioning strategy of a mall is critical to its success.

\section{NEED FOR A NEW MALL POSITIONING APPROACH}

In this sense, it may be argued that a mall is selling space, which is made to attract both retailers and shoppers. Nevertheless, unlike typical space leasing, a mall does not follow simple laws of demand and supply because it can draw different catchments of shoppers and provide 
different mixes of retailers by different positioning strategies. In other words, both supply (of retailers) and demand (of shoppers or space) are partially endogenous. It is so complicated that the traditional theories of economics and models of business cannot be applied. Therefore, a new theoretical model of shopping mall that is contingent on the interactive plays among shoppers, retailers, and mall developers or operators shall be formulated. A positioning strategy shall be regarded as a vehicle for creating a sustainable competitive advantage of a mall. ${ }^{6}$

Unfortunately, there have so far been no systematic and scientific studies on this topic, let alone any analytical models. Basically, the industry relies heavily on the experience of retailers, gut feelings and lessons learned from trial and error. In this climate, although operators of shopping malls have tried to counter the challenges posed by their competitors and changes in market conditions, they have had limited success in defending their positions. This can be ascribed to the failure of mall operators to identify and implement distinctive and focused market positioning strategies that would ensure their places in the retailing market. Despite a lot of ink being spilt over the determinants of the rents and revenue of a shopping mall, ${ }^{7-10}$ the strategic positioning of shopping malls has received insufficient academic attention.

With this background, a conceptual framework has been formulated with a community ecology ${ }^{11}$ metaphor on the operation of a mall in this study. The origins of this study lay in two sets of ideas. First, the harmonious balance of benefits-and-costs among retailers, shoppers and mall operators within a mall works like the homeostasis of a predatorand-prey ecological community. Secondly, competition among malls and shops-on-street for retailers and shoppers follows the interspecific interaction theory in community ecology, which posits that community patterns are a consequence of a hierarchy of interactive processes. ${ }^{12}$ These interactive processes are not limited to pure competition (for prey), but include also cooperation, mutualism, parasitism and predation, etc. Based on this eco-metaphor, a strategic positioning system can then be devised for optimising performance of a mall. This proposed community ecology model for malls has far-reaching implications for practitioners in operating new and existing shopping malls.

\section{PREVIOUS STUDIES ON MALL POSITIONING What is strategic positioning?}

The strategic positioning of a business, whether or not it is to sell products, is an essential activity in planning the business. This concept is closely related to market segmentation, which is about the subdividing of a market into distinct subsets of customers according to their needs and the ways they buy and use products and services. ${ }^{13,14}$ Strategic positioning refers to making decisions on a particular market segment that will be served by businesses and tailoring a programme to meet specific customer needs in that segment. ${ }^{14}$ In addition, strategic positioning helps shape the way a product or service and the place where it is offered will be perceived by consumers relative to its competitors, with reference to its important attributes. ${ }^{15}$ In other words, it is customer-dependent, and 
for these reasons, many corporations try to improve their performance by broadening their access to customers in existing markets or by altering the prevailing hierarchical structures or practices within their industry. Therefore, strategic positioning is undoubtedly the core of every business.

From the above, there is no reason why strategic positioning does not apply to the operation of a shopping mall. As more shopping malls appear, they have to differentiate themselves from their competitors in order to survive. Hence, strategic positioning, which is a display of differences, becomes an increasingly important part of the operation of a mall. ${ }^{16}$

\section{Shopper-focused strategic positioning}

In the heyday of mall development, its strategic positioning put much emphasis on the shopper market. For instance, a study by Baker and Funaro in 1951, one of the earliest studies on the planning of retail properties, suggested that the positioning of a mall depended on (1) the size of the catchment area, (2) the number of households in the catchment area and (3) the demographics and preferences of these households, such as disposable income and spending mode. ${ }^{17}$ While suggesting that the extent and nature of competing centres should be considered, Black and his co-workers in 1983 advocated that customer mix was a crucial retaining element. ${ }^{18}$ Furthermore, Casazza in 1985 developed an analytical method for mall positioning. ${ }^{19}$ Basically, he considered the customer factors suggested in the previous two studies. Further to these factors, Casazza also took population growth and changes in the general economic situation into account.

A review of the works by these aforementioned authors revealed that the fundamental difference between the positioning of a shopping mall and the mere positioning of a product has been largely ignored in academia and among practitioners as well. Indeed, what makes mall positioning distinctive is the dual market consideration in the process. In the retail industry, for example, there is only one type of 'customer' to business operators. They are the ones who spend money on their products, that is the shoppers. Conversely, from the perspective of an operator of a shopping mall, there are two groups of 'customers'. They are shoppers and retailers. In this regard, the positioning strategy of a mall must consider the segmentation of these two 'customer' markets. A superior positioning strategy should entail a good match between the segments selected from these two markets of 'customers'.

\section{Competition and cooperation in the mall business}

Another interesting point noted in these studies is that the relationship between different shopping malls has commonly been treated as a rivalry. These authors generally fancied that the more shopping malls or retailing entities exist in the same catchment area, the fiercer the competition would be. While competition is commonplace in the business world, there are other options for business entities to coexist. Cooperation, whether or not it is through alliances, is one example. Unfortunately, these authors overlooked the synergy of the interaction hierarchy among different 'species' of malls in the community ecology. Casazza even argued that a 
shopping mall could not generate new business or create new buying power, but it could attract shoppers from existing competitors or capture the increase in their purchasing power due to population growth. ${ }^{19}$

Contrary to Casazza's view, Beyard and his co-workers in 2001 suggested that the rise of new malls in a region might not necessarily reduce the 'slice' of the pie enjoyed by each existing mall. While they proposed strategic mall positioning to assess a mall's potential distinctiveness within a predetermined catchment area, they also argued that strategic positioning sometimes involved 'turning potential competition into a source of support' ${ }^{20}$ This view is particularly true when the overall community pattern of a cluster of shopping malls and shops in the street is considered. Indeed, what makes mall shopping different from street shopping are the cooperative-competitive (or 'coopetition' $\left.{ }^{21}\right)$ interactions among retailers within a mall. The tenant mix, the theme and the variety of commodities and forms of entertainment seem to bond magically altogether into a 'Gruen Transfer'.22

Such a concept of 'coopetition' can essentially be applied to the relationship between different malls in the market. Based on this ideology, Vinh $^{23}$ studied the coopetition among malls in Singapore by illustrating that the synergy of 'cluster networks' of malls and shops in the street could be achieved by linking diverse marketing and leasing programmes, infrastructure, and consumer products into an dynamic model for the overall prosperity of cluster networks, and eventually the nation.

\section{A NOVEL MALL POSITIONING MODEL}

Every shopping mall works in a retail network that covers its catchment area. The moves that a shopping mall makes, to varying degrees, affect the state of its retailing network, which in turn will ultimately affect the mall's performance (and also the performance of other malls). The interaction model suggested by Beyard and his co-workers contributes a great deal to the body of knowledge in strategic mall positioning. Rather than foment rivalry, the coexistence of different malls in a network and within different networks can be explained by their cooperation. This feature of the retailing market makes it look like an ecosystem where predation is an interacting result of the forced partition of foraging areas and collusion.

\section{Retailing and ecosystem}

Since the pioneering works of Charles Darwin ${ }^{24}$ and Alfred Wallace ${ }^{25}$ in the 19th century, the study of ecology has been developed into a highly sophisticated discipline. Interactions among different species have been investigated by community ecologists. ${ }^{26}$ Different community patterns were the results of the different interactions, including competition, predation and mutualism among different species. ${ }^{27}$ Dynamic predator-prey models that highlighted the importance of cooperation for sustainable coexistence were developed. ${ }^{28,29}$

The application of the concepts of ecology to other disciplines is not new. Such knowledge transfer has been done before. For example, 
business competition was analysed by Moore ${ }^{30}$ in 1993 as a predatorprey relationship in a business ecosystem model. Moore's business ecosystem model provided a framework for understanding business competition and strategy development. In 2004, Iansiti and Levien ${ }^{31}$ extended the application of the eco-model to study the network of individual business entities in a particular industry. They further illustrated their eco-model by making reference to the IT industry.

The operation of a shopping mall, which is always a kind of business, has also been studied with an ecosystem model. Perhaps, Cha is the first one who considered retailing as community ecology. In his work, Cha put forward that a retailing industry was an ecosystem in which species (retailers and shoppers) continuously breed, were born, adjusted, mutated, aged and died. ${ }^{32}$ The shoppers visiting the shops look for the goods they desire 'with senses heightened like animals searching the land for sustenance' ${ }^{32}$ Furthermore, Underhill regarded shopping malls as living creatures with a 'shopping mall's DNA'. ${ }^{33}$ Nevertheless, both Cha and Underhill did not formulate any holistic framework to model the relationship between stakeholders in a retailing network, which is essential to the development of a mall positioning strategy.

To arrive at an appropriate analogy between a retailing network and an ecosystem, it is necessary to have a clear definition of the analogues and the targets. In this study, a retailing ecosystem is comprised of numerous communities that are formed by three principal components, namely the malls, retailers and shoppers. With reference to the works by Hairston et al. in $1960,{ }^{34}$ these components are compared to carnivores, herbivores and producers. The analogy is shown in Table 1.

Following the line of thought that a mall (a carnivore) preys on retailers (herbivores) but provides utilities (food) for shoppers (producers), ${ }^{34}$ the interactive relationship between these components from different perspectives are depicted in Figure 1. In a community ecological system, producers, which are mainly plants, provide food for herbivores.

Herbivores consume the constructed plant organic molecules for nutrition to run their metabolism. They then become food for the carnivores. The carcasses or excrement of carnivores in turn become vital nutrients for the growth of plants.

In Figure 1, shopping malls prey on retailers through retail space leasing. The food or sustenance in a mall is rental income. Retailers, on the other hand, prey on shoppers by selling goods and services. The major difference between shops in the street and shopping malls lies in the curved arrow in Figure 1. A mall provides food (utilities) to shoppers by different positioning strategies, which in turn attracts retailers to the field. These utilities are not necessarily there, but they have to be made available by the mall operator. Therefore, the three stakeholders form a very interesting symbiotic relationship, which results in a dynamic equilibrium of the ecosystem.

The double arrows linking the shopping malls and other malls and shops-on-street represent a range of possible modes of relationship. These carnivores can be in a competitive, cooperative or parasite-host relationship in the same catchment area. If truth is to be told, Figure 1 is generalisation of reality. The predation process described is a simple 
Table I: An analogy between retailing and ecological systems

\begin{tabular}{ll}
\hline Retailing market & Eco-system \\
\hline Shopping malls & Carnivores (predators of retailers) \\
Retailers & Herbivores (prey for malls/predators of shoppers) \\
Shoppers & Producers (preys for retailers/consumers of food provided by malls) \\
Retailing environment of a mall & Community \\
Retailing network & Eco-system \\
\hline
\end{tabular}

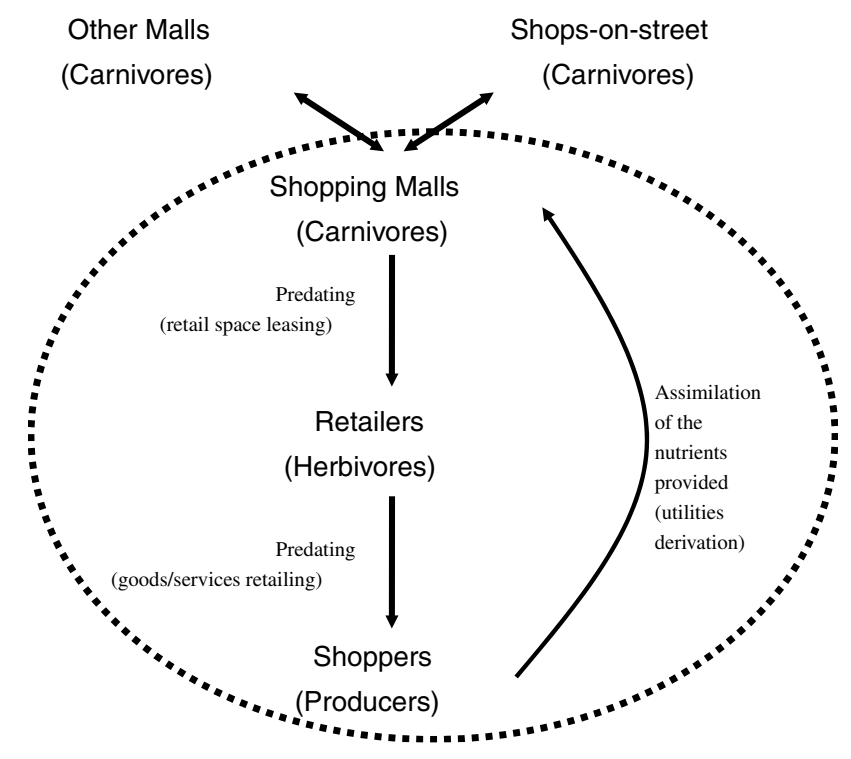

Figure I: Relationship between different components in a retailing environment

abstraction of what actually happens in a variety of different types of mall ecosystems of much greater complexity. In a real mall-community ecological system, there can be an unlimited number of species of malls, retailers and shoppers in the ecosystem. The combinations of these components are theoretically endless. The survival of a particular species of retailer, however, is determined by the success rate of predation, density and characteristics of shoppers, and competition and cooperation among retailers in the ecosystem. Similarly, whether a species of mall can survive also depends on the successful rate of predation, density and characteristics of retailers, as well as the competition and cooperation among malls within the ecosystem.

Interestingly, in order to feed on retailers, a mall has to provide utilities to shoppers, who in turn attract retailers to the mall. This can be achieved by providing a pleasant environment for shoppers to patronise the mall. Elements of leisure and entertainment, such as cinemas and ice rinks, help provide leisure facilities to shoppers. Since such draws and predation by a mall consume resources (energy), the mall operator has to strategically select the right kinds and mix of retailers and target shoppers. Coopetition between retailers and among malls work according to Darwin's law of natural selection, in which 'the fittest survive'. ${ }^{24}$ 


\section{Eco-metaphor of the mall positioning strategy}

With the establishment of the importance of the strategic positioning of shopping malls in the previous section, we move on the way in which a shopping mall is strategically positioned. Founded on the above analogy, we have proposed an eco-metaphor of the mall positioning strategy, as shown in Figure 2. The strategy is underpinned by two objectives: (1) for the prey to maximise their utilities obtained; and (2) for the predators to have as much prey as possible. It is relatively simple to achieve the first objective. For example, a retailer can maximise its utilities by choosing a mall with the best terms of tenancy, such as the lowest rent, the most generous terms of renewal and the most rent-free periods, ceteris paribus. In the retailing industry, turnover rent (or overage) provision is also one of the common attractive terms in tenancy agreements. Similarly, a shopper can optimise his or her utilities by calculating the savings in transportation costs, the maximisation of the benefits of shopping at a certain mall and his or her possible enjoyment of the facilities there.

In light of the second objective, a mall operator can help reduce the competition among retailers by adopting appropriate leasing strategies, such as limiting the number of competitors, establishing a theme of trades and composing a harmonious mix of retailers. These leasing strategies prevent a reduction in the number of prey for each retailer due to excessive competition. In addition, to attract as many retailers as possible to a mall, a mall operator can also help draw in prey for retailers through good architectural design, promotional activities and effective property management. The abundance and quality of prey, however, are usually predetermined by the location chosen.

Generally speaking, there are six major determinants of a successful mall positioning strategy. They are Location, Architectural Design, Leasing Strategy, Promotional Activities, Property Management and

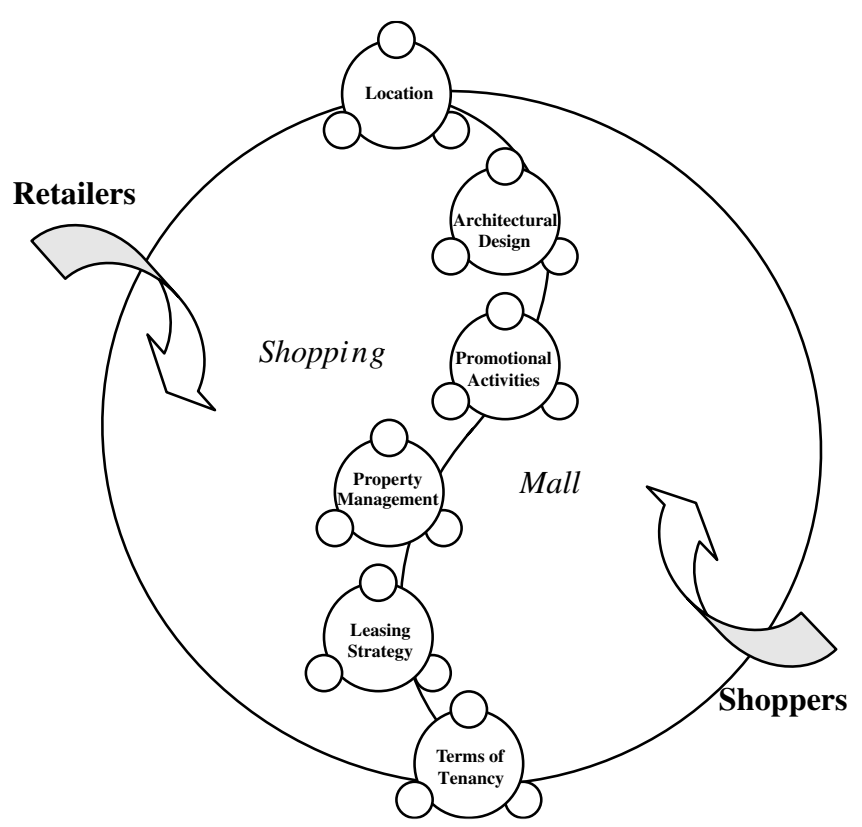

Figure 2: The eco-metaphor of a mall positioning system 


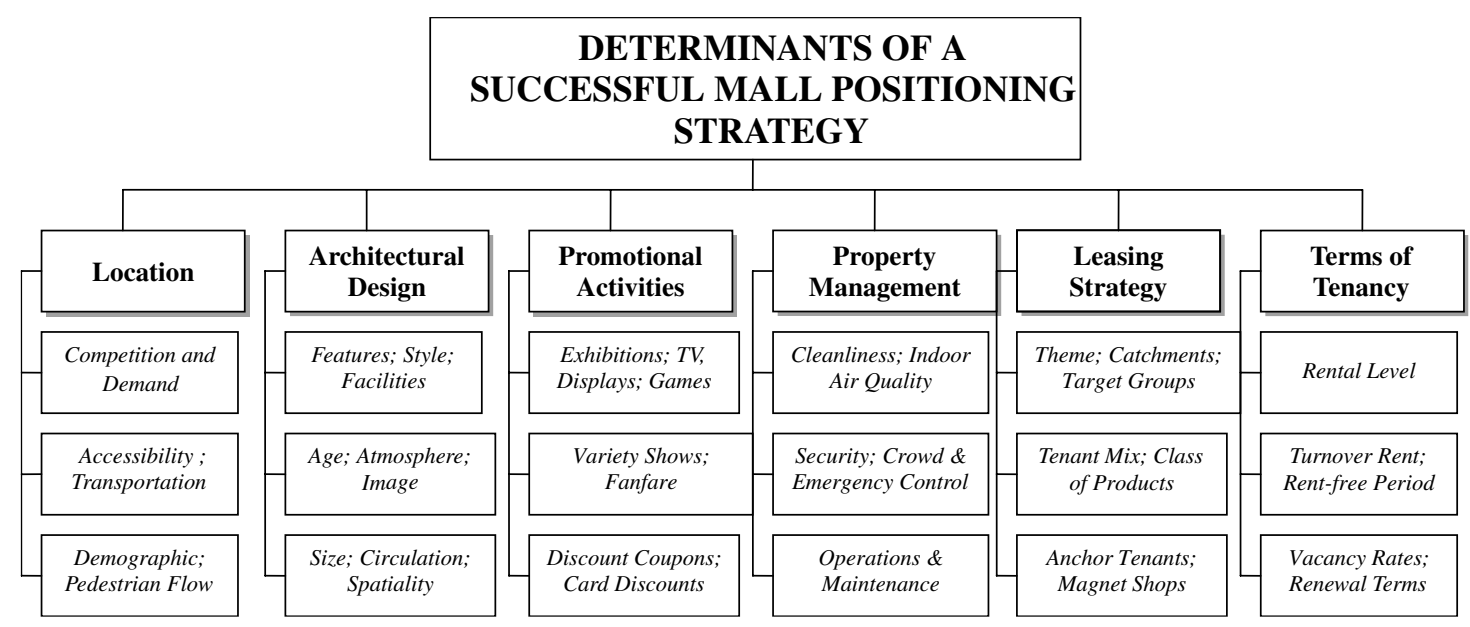

Figure 3: A $6 \times 3$ matrix of the factors determining the success of a mall positioning strategy

Terms of Tenancy. These factors work like the genetic codes of living organisms, as shown in Figure 2. Variations of these genetic codes are responsible for the unique characteristics, and consequently the success or failure, of a mall. By eco-metaphor, the success of a mall rests on its structure, functions and transformations of these genes.

Each genetic code is composed of three elements, as shown in a $6 \times 3$ matrix in Figure 3. Location is represented by the competition and demand of predators and prey, accessibility to a mall, and the demographics of the district. Architectural Design is divided into the provision of facilities, atmosphere, and size and spatiality. Leasing Strategy facilitates the development of the required catchments, tenant mix and anchorage. Promotional Activity refers to exhibitions, fanfare and discount coupons. Property Management addresses the cleanliness, security and maintenance of the mall. Terms of Tenancy refers to the rental levels, turnovers of rent provisions and terms of renewal. To achieve a competitive positioning strategy, these factors should be considered seriously in a holistic manner.

\section{CONCLUSIONS}

This paper arose out of a degree of frustration with the academic literature on the strategic positioning of shopping malls. While it has been recognised that the strategic positioning of a shopping mall is essential to its success, there had been, so far, no systematic and scientific study on this topic. For this reason, this study constitutes a pioneer and scientific look into the subject.

Within a retailing network, every mall interacts with each other and other retailing facilities, such as shops in the street, through competition and cooperation. In this sense, retailing is rife with ecological analogies. The analogy between a retailing network and a biological ecosystem can aid in the understanding of the retailing industry by vividly highlighting certain pivotal concepts. A shopping mall is a unique, but ubiquitous, commercial entity in both the marketing and real estate industries. It does not produce any goods or services directly consumed by shoppers, but 
instead provides an ecosystem (a platform) for predators and prey to coexist and prosper. There are several interactive 'plays' among predators, as well as between predators and prey.

The analogy between a retailing network and an ecosystem drawn in this study has at least two influential practical implications for developers and operators of contemporary shopping malls. First, this study suggested that strategic market positioning is a dynamic exercise. It is not a one-off process because interdependency is central to a mall's performance. A change in a mall's positioning may lead to changes in other malls' positioning and vice versa. A mall developer or operator cannot make any decisions without first determining what the effects will be on the entire retailing network or ecosystem. Otherwise, it will be at the cost of ignoring the true effects of the decisions.

Secondly, this study provided a holistic framework on the relationship between different stakeholders in a retail property market. While formulating their positioning strategies, developers and operators of shopping malls should consider the conceptual framework provided in this study. Defining a mall's ecosystem and identifying its place in the system will help promote the overall health of the ecosystem, as well as its own long-run survival and prosperity. In addition, the $6 \times 3$ matrix of success determinants may provide a basis for comparing or benchmarking the performance of the strategic positioning of different malls.

\section{References and Notes}

1. Bauman, Z. (1993). From pilgrim to tourist-or a short story of identity, in Hall, S. \& du Gay, P. (eds) Questions of Cultural Identity, Sage, London, pp. 18-36.

2. Gruen, V. (1960) Shopping Towns USA: The Planning of Shopping Centres, Reinhold, New York.

3. Eaton, B. C. \& Lipsey, R. G. (1982). An economic theory of central places. The Economic Journal. 92, 56-72.

4. Goss. (1993). The magic of the mall-an analysis of form function and meaning in the contemporary retail built environment. Annals of the Association of American Geographers. 83(11), 10-47.

5. Hardwick, M.J. (2004) Mall Maker: Victor Gruen, Architect of an American Dream, University of Pennsylvania Press, Philadelphia.

6. LeHew, M.L.A. \& Fairhurst, A. E. (2000). US shopping mall attributes: an exploratory investigation of their relationship to retail productivity. International Journal of Retail and Distribution Management. 28(6), 261-279.

7. Benjamin, J.D., Boyle, G.W. \& Sirmans, C.F. (1990). Retail leasing: the determinants of shopping center rents. AREUEA Journal. 18(3), 302-312.

8. Sirmans, C.F. \& Guidry, K.A. (1993). The determinants of shopping center rents. The Journal of Real Estate Research. 8(1), 107-115.

9. Tay, R.S., Lau, C.K. \& Leung, M. S. (1999). The determination of rent in shopping centres: some evidence from Hong Kong. Journal of Real Estate Literature. 7(2), 183-196.

10. Hui, E.C.M., Yiu,C. Y. \& Yau, Y. (2006), Rent Determinations of Government-owned Retail Properties: A Study on the Link, Working Paper, Department of Real Estate and Construction, the University of Hong Kong.

11. According to Wikipedia (the Free Encyclopedia available at http://en.wikipedia.org/ ), Community ecology studies the distribution, abundance, demography, and interactions between populations of coexisting species, and it focuses on relationships between species, including the study of food webs, energy flow, and nutrient flow.

12. Schoener, T.W. (1986). Overview: kinds of ecological communities-ecology becomes pluralistic, in Diamond, J. \& Case, T.J. (eds) Community Ecology, Harper \& Row, New York, pp. 467-479.

13. Kolter, P. (1976) Marketing Management, Prentice-Hall, Engelwood Cliffs, NJ. 
14. Biggadike, E. R. (1981). The Contributions of marketing to strategic management. The Academy of Management Review. 6(4), 621-632.

15. Kolter, P. (1999) Principles of Marketing, International Edition, Prentice-Hall, Engelwood Cliffs.

16. Ibrahim, M. F., Sim, L. \& Chen, F. S. (2003). Positioning of shopping centres within the retail market of Singapore. Pacific Rim Property Research Journal. 9(1), 61-78.

17. Baker, G. H. \& Funaro, B. (1951) Shopping Centers: Design and Operation, Reinhold Publication, New York.

18. Black, J. T., Howland, L. \& Rogel, S. L. (1983) Downtown Retail Development: Conditions for Success and Project Profiles, The Urban Land Institute, Washington, DC.

19. Casazza, J. (1985) Shopping Center Development Handbook, The Urban Land Institute, Washington, DC.

20. Beyard, M. D., Braun, R., McLaughlin, H., Philips, P. \& Rubin, M. S. (2001) Developing Retail Entertainment Destinations, The Urban Land Institute, Washington DC.

21. 'Coopetition' was firstly coined by Charles F. Sabel, in his paper Work and Politics: The Division of Labor in Industry, to describe the integral relationship between cooperation and competition in a dynamic economic system. T. Vinh applied it in shopping mall operations (see reference 23).

22. Farrell, J. J. (2003) One Nation under Goods: Malls and the Seductions of American Shopping, Smithsonian Books, Washington, DC.

23. Vinh, T. (2001). Coopetition in Chung, C.J., Inaba, J., Koolhaas, R., Leong, S.T. \& Cha, T.W. (eds) Harvard Design School Guide to Shopping, Taschen, Köln, pp. 205-224.

24. Darwin, C. R. (1859) On the Origin of Species, Murray, London.

25. Wallace, A. R. (1878) Tropical Nature and Other Essays, MacMillan, London.

26. Odum, E. P. (1959) Fundamentals of Ecology, W.B. Saunders Co., London.

27. Schoener, T. W. (1986). Overview: Kinds of ecological communities-ecology becomes pluralistic, in Diamond, J. \& Case, T.J. (eds) Community Ecology, Harper \& Row, New York, pp. 467-479.

28. Lotka, A. J. (1925) Elements of Physical Biology, Williams and Williams, Baltimore.

29. Volterra, V. (1926). Variations and fluctuations in the numbers of individuals in animal species living together reprinted in 1931, in Chapman, R.N. (ed.) Animal Ecology, McGrawHill, New York.

30. Moore, J. (1993). Predators and prey: a new ecology of competition. Harvard Business Review. 71(3), 75-86.

31. Iansiti, M. \& Levien, R. (2004). Strategy as ecology. Harvard Business Review. 82(3), 68-78.

32. Cha, T. W. (2001). Ecology, in Chung, C.J., Inaba, J., Koolhaas, R., Leong, S.T. \& Cha, T.W. (eds) Harvard Design School Guide to Shopping, Taschen, Köln, pp. 321-335.

33. Underhill, P. (2004) Call of the Mall, Simon \& Schuster, New York.

34. Hairston, N. G., Smith, F. E. \& Slobodkin, L. B. (1960). Community structure, population control, and competition. American Naturalist. 94, 421-425. 